\title{
SOCIAL SELF OF DELINQUENT JUVENILES: PERSONALITY DIMENSION
}

\author{
Virna Zh.P., Koshyrets V.V., Benediuk V.I. \\ Lesya Ukrainka Eastern European National University, Volya Avenue, 13, Lutsk, 43025, Ukraine \\ E-mail: annavirna@ukr.net, https://orcid.org/0000-0001-8134-2691
}

Received July 26, 2018

The article presents theoretical and empirical research of the personality and behavioral content of the social Self of delinquent juveniles. The theoretical argumentation of the problem relates to the necessity of studying the personal characteristics of the societal psyche of a delinquent, in which the integral picture of his social Self is reflected. It is emphasized that the sphere of personal problems affects the formation of social experience of delinquent young men and is characterized by typical symptom complexes of their personal qualities and style of interpersonal interaction. The purpose of the presented material is to study the personality and behavioral content of the social Self of a delinquent juvenile, characterized by typical symptom complexes of his personality characteristics and the style of interpersonal interaction. On the basis of the analysis and theoretical generalization of the problem, the program of empirical research has been worked out; it includes methods of observation and testing, as well as the complex of methods used for mathematical processing of the results, enables to specify the theoretical positions in the form of real psychological facts: in the assessment of "social Self" the positions of extraversion, spontaneous aggressiveness and selfishness dominate, and in the assessment of "actual Self" physical aggressiveness, irritability and negativism prevail; an aggressive form of desire for domination over others and selfishness in interpersonal contacts and inclination to rivalry are noted. It is proved that the personal dimension of "social Self" is localized in the symptom of such personality and behavioral characteristics of delinquent juveniles as physical, verbal and reactive aggressiveness, irritability, imbalance, aspiration for independence and self-centered conviction. It is noted that the obtained results can be used as psychodiagnostic guidelines for the development of specific psychocorrective measures with the obligatory use of consulting elements aimed at actualization of reflection, psychogenesis and logogenesis in the course of experiencing crisis of self-determination of delinquent juveniles.

KEY WORDS: social Self, delinquent behavior, aggressiveness, egoism, imbalance, independence, delinquent juveniles.

\section{СОЦІАЛЬНЕ Я ДЕЛІКВЕНТНИХ ЮНАКІВ: ОСОБИСТІСНИЙ ВИМІР}

Ж.П. Вірна, В.В. Коширець, В.І. Бенедюк

Східноєвропейський наџіональний університет імені Лесі Украӥнки, пр. Волі, 13, м. Луцьк, 43025, Украӥна $\mathrm{y}$ роботі представлено теоретико-емпіричне вивчення особистісно-поведінкового змісту соціального Я деліквентних юнаків. Теоретичне обгрунтування проблеми стосується необхідності вивчення особистісних властивостей соцієтальної психіки деліквента, у якій відображається його цілісна картина соціального Я. Підкреслюється, що сфера особистісних проблем впливає на формування соціального досвіду деліквентних юнаків i характеризується типовими симптомокомплексами їх особистісних властивостей та стилю міжособистісної взаємодії. Метою презентованого матеріалу $€$ вивчення особистісно-поведінкового змісту соціального Я деліквентного юнака, що характеризується типовими симптомокомплексами його особистісних властивостей та стилю міжособистісної взаємодії. На основі аналізу i теоретичного узагальнення проблеми, розроблено програму емпіричного дослідження, що вміщує методи спостереження $\mathrm{i}$ тестування, а також комплекс використаних методів математичної обробки результатів дає змогу конкретизувати теоретичні положення у вигляді реальних психологічних фактів: в оцінюванні «соціального Я» домінуючу позицію займає екстравертованість, спонтанна агресивність та егоїстичність, а в оцінюванні «актуального Я» превалює фізична агресивність, дратівливість і негативізм; відмічені агресивна форма прагнення домінування над іншими та егоїстичність у міжособистісних контактах і нахили до суперництва. Доведено, що особистісний вимір «соціального Я» локалізований у симптомокомплексі таких особистісно-поведінкових властивостей деліквентних юнаків як фізична, вербальна і реактивна агресивність, дратівливість, неврівноваженість, прагнення до незалежності та егоїстичної переконаності. Зазначено, що отримані результати можуть бути використані як психодіагностичні орієнтири для розробки конкретних психокорекційних заходів з обов'язковим використанням консультаційних елементів, які спрямовані на актуалізацію рефлексії, психогенезу і смислогенезу у перебігу переживань кризи самовизначення деліквентних юнаків.

КЛЮЧОВІ СЛОВА: соціальне Я, деліквентна поведінка, агресивність, егоїстичність, неврівноваженість, незалежність, деліквентні юнаки.

\section{СОЦИАЛЬНОЕ Я ДЕЛИКВЕНТНЫХ ЮНОШЕЙ: ЛИЧНОСТНОЕ ИЗМЕРЕНИЕ}

Ж.П. Вирна, В.В. Коширец, В.И. Бенедюк

Восточноевропейский национальный университет имени Леси Украинки, пр. Воли, 13, г. Луик, 43025, Украина В работе представлено теоретико-эмпирическое исследование личностно-поведенческого содержания социального Я деликвентных юношей. Теоретическое обоснование проблемы касается необходимости изучения личностных свойств (C) Вірна Ж. П., Коширець В. В., Бенедюк В. І., 2018 
социэтальной психики деликвента, в которой отображается его целостная картина социального Я. Подчеркивается, что сфера личностных проблем влияет на формирование социального опыта деликвентных юношей и характеризуется типичными симптомокомплексами их личностных свойств и стиля межличностного взаимодействия. Целью презентированного материала является изучение личностно-поведенческого содержания социального Я деликвентного юноши, которое характеризуется типичными симпотомокомплексами его личностных особенностей и стиля межличностного взаимодествия. На основе анализа и теоретического обобщения проблемы, разработано программу эмпирического исследования, которая содержит методы наблюдения и тестирования, а также комплекс использованных методов математической обработки результатов позволяют конкретизировать теоретические положения в виде реальных психологических фактов: в оценке «социального Я» доминирующую позицию занимает экстравертированность, спонтанная агрессивность и эгоистичность, а в оценке «актуального Я» превалирует физическая агрессивность, раздражительность и негативизм; отмечены агрессивная форма стремление доминирования над другими и эгоистичность в межличностных контактах и склонность к соперничеству. Доказано, что личностное измерение «социального Я» локализировано в симптомокомплексе таких личностно-поведенческих свойств деликвентных юношей как физическая, вербальная и реактивная агрессивность, раздражительность, неуравновешенность, стремление к независимости и эгоистической убежденности. Отмечено, что полученные результаты могут быть использованы как психодиагностические ориентиры для разработки конкретных психокоррекционных мероприятий с обязательным использованием консультационных элементов, направленных на актуализацию рефлексии, психогенеза и смислогенеза в ходе переживаний кризиса самоопределения деликвентных юношей.

КЛЮЧЕВЫЕ СЛОВА: социальное Я, деликвентное поведение, агрессивность, эгоистичность, неуравновешенность, независимость, деликвентные юноши.

Formulation of the problem. The complexity of social, economic and political situation in Ukraine has led to a large number of changes, and often these changes are manifested in the negative processes that are accompanied by criminality in the age range of early becoming of social Self of a personality. That goes about juvenile delinquency, which has recently become the most diverse forms of organized crimes. This situation gives rise to a number of problems of legal, pedagogical, social and psychological character. The target of the presented research is to study the personality qualities of the social Self of juveniles with delinquent behavior, which, in our opinion, will enhance the adaptive potential of a juvenile personality, will optimize his socialization and harmonize personality development.

Analysis of recent research and publications. The analysis of psychological and legal literature testifies that Yu. Antonian, Ya. Goshovskyi, V. Hulden, N. Kreidun, N. Maksimova, I. Mudrak, N. Malysh, V. Pirozhkov, M. Filippov, V. Khudyk and others addressed the decisions on issues of delinquent behavior of adolescents and juveniles, as well as juvenile criminality, who stated that juvenile delinquency involves irresponsibility, inadequate self-control and inability to analyze the consequences of own illegal actions. Weak motivation to self-control and reflection of adolescent offenders leads to the fact that Self-concept of these young people is very much changed.

Singling out of the previously unsolved parts of the general problem. The purposeful search of the works that would solve the problem of peculiarities of juvenile offenders' personality showed, that the aspects of studying of personality relations of adolescents and juveniles in closed type institutions, deformation of a personality of a young person, beginnings of aggressiveness or conflict, as well as manifestations of segregation and discrimination, anxiety and depression etc. are most often considered. However, practicing psychologists require in-depth empirical researches of delinquent personality, who, on the one hand, experiences the influence of actual age factors (transitional age, puberty, adolescent crisis, etc.), and on the other hand, is under the influence of numerous negative social factors that are painfully reflected in a psyche, and even can lead to personality disorders. Therefore, we consider that in this perspective, in studying of the societal psyche of a delinquent, the diagnostic fixation of his personality characteristics is necessary, where the crystallization of his integral picture of social Self would be seen.

The aim of this empirical review is the replenishment of psychological material concerning the studying of personality and behavioral content of the social Self of delinquent juvenile, that is characterized by typical symptoms complexes of his personality characteristics and style of his interpersonal interaction. 
Presentation of the main research material. The carried out theoretical and methodological analysis of the problem in psychological, pedagogical and legal literature provides all grounds for asserting that personality self-determination of young people is means of reconciliation with the contradictions of the world and is the result of experienced identity crisis, where personality maturity is achieved $[1 ; 3 ; 4 ; 5$ and others.]. The sensitive period for this is youthful age as the age of individual content formation and construction of one's own life perspective.

Youthful self-determination can be seen as the result of identification and internalization of own experiences, which, in its turn, becomes a condition for a positive exit from a crisis. While the process of constructive experience of personality self-determination is violated, a juvenile may resort to asocial, and even to delinquent behavioral manifestations. This means that there is a complete failure of the development of criticality and objectivity in the reality perception, which, in its turn, destroys the adaptive capabilities of a personality. Transformation of emotions in youth age is associated with the degree of their awareness that is a reflection of personality maturity. The basis for personality maturity is social maturity as the main condition for the development of morality and spiritual qualities of a person.

It is known that the main concept used to explain the driving forces of human activity is personality and motivational sphere. It is impossible to disclose the process of personality formation of a youth personality with illegal behavior, not taking into account what role his needs, motives, aspirations, desires play in this process. Therefore, studying the motivational sphere of the personality of an adolescent with unlawful behavior is a necessary step in understanding the structure of such a person.

An overview of scientific achievements in the study of delinquent behavior of adolescents and teenagers in native and foreign psychology has shown that most often delinquent behavior is caused by irresponsibility, violation of moral and ethic norms, and the desire for achievements by means of unlawful acts (V. Baranov, I. Videnieyeva, V. Morgun, I. Pokhlibna, F. Rice, K. Siedykh, P. Filonova, and others). Among the methodological approaches dealing with delinquent behavior, the most powerful are: E. Durkheim theory of social norms; T. Parsons doctrine of social norm, social control and the institute of norms in structuralism; P. Worsley theory of absolute norms and deviations connection, N. Smelser theory of social determinants of the collective behavior, deviations and social control; P. Watzlavick position of subjectivity of norm in constructivism and biopsychological norms and pathologies in the theories of S. Freud and C. Lambroso etc. The scientific concept of aggressive behavior as a form of self-affirmation (A. Bandura, A. Bass, M. Lazarus) and the concept of "labelling", which considers such psychological phenomena as "stained reputation", "stigmatization", "sticking labels" ( G. Becker, E. Hoffman) have also got scientific respectability. The basic part of modern studies in Ukrainian psychology emphasizes the influence of social factors that play an important role in the genesis of behavioral disorders ("difficult adolescent", "socially neglected teenager", "socially deviant teenager", "social outsider", etc.). That is about non-pathological forms associated with the phenomena of microsocial and pedagogical neglect, conditions of ignoring, chronic lack of information, etc. (M. Avdiyevska, V. Kagan, V. Labunska, E. Eidemiller, V. Yustytskis, etc.); an experience of chronic frustration of the basic needs of emotional acceptance by other people, sympathy to other people, self-affirmation and meaning of life (T. Hovorun, V. Kovaliov, V. Mukhina, A. Lichko, L. Sokuryanska and others).

Juvenile offenders have such features of psyche that distinguish them from ordinary teenagers. They are characterized by the presence of a vivid protest against their existence in the surrounding environment; they are heavily adapted; their poorly controlled behavior is accompanied by severe aggression, anxiety and a sense of discomfort. Among the main factors contributing to the development of delinquent behavior, scientists classically distinguish: 1 - the moral immaturity of the individual, manifested in the negative attitude towards studying, the lack of social positive activity, settings, etc.; 2 - violation of the social microenvironment, often associated with staying in an incomplete family, distortion of family relations, incorrect education; 3 - individual biological features of the personality, associated with hereditary burden 
on mental illness and alcoholism, somatic diseases, neuroinfections etc.; 4 - individual psychological features and neuropsychological anomalies of the person, manifested in increased anxiety, impulsivity, social maladaptation, neurosis and psychopathy. In any case, there is a relationship between the individual psychological characteristics of juvenile offenders and their behavior and peculiarities of criminal activity [2].

Among the presented factors that influence the development of delinquency in the behavior of teenagers and adolescents, social maturity takes the first place. After all most of the social life a person adapts to the environment, learning its norms and values. Therefore, when it comes to social adaptation reserves of a juvenile personality, it is necessary to study his social experience.

Careful theoretical analysis of the problem allowed to approach its empirical study. For this purpose, a program of empirical research was made up, the main stages and methodological support were identified. The survey was carried out on a sample of young men who are registered in the Children's Room of the Police of the City Department of Internal Affairs in Volyn region $(n=24)$ and includes one diagnostic section. For the study of the personality and behavioral content of the social Self of a delinquent juvenile, characterized by typical symptom complexes of his personality characteristics and the style of interpersonal interaction, a series of diagnostic methods was proposed: Q-sort Technique by W.Stephenson; the BussDurkee Hostility Inventory (BDHI) (in the adaptation of O. Osnytskyi); the method of diagnosis of interpersonal relations T. Liri; Freiburg Personality Inventory (form B). The results of the psychodiagnostic tests carried out carefully were processed with a help of mathematical statistical methods, in particular using the analysis of mid-range values, Pearson correlation coefficient of sum products, as well as the Student's tcriterion to determine the significance of the correlation relations.

In the process of working up, the mid-range data interpolation made it possible to carry out an interpretive analysis concerning the correlation of social maturity and the manifestation of delinquent behavior of young men, characterized by typical symptom complexes of their personal characteristics and the style of interpersonal interaction.

According to the results of the Q-sort Technique by W.Stephenson, the following indicators of evaluation of "social Self" were recorded: the tendency "dependence - independence", which is defined as the internal desire of the individual to accept group standards and values (social, moral and ethical), takes the dominant position; a low indicator of the "communicability" tendency testifies to the lack of contact, the desire to form emotional connections in the group; the level of expression of the tendency "acceptance of the struggle" confirms the desire to achieve a high social status. When the respondents were offered to do the same task, only evaluating their "actual Self" ("What am I in different situations?"), then the distribution of indexes of the main trends of behavior in the group received a slightly different view, namely: the domination of the tendency "dependence - independence", but at the same time, the average level of manifestation received the tendencies of "avoiding the struggle" as a desire to deviate from interaction, to maintain neutrality in group disputes and conflicts, to show inclination to compromise solutions; and the tendencies of "communicability" as a contact, the desire to form emotional connections both in their group and beyond its borders.

After carrying out a method for determining the aggressiveness - the Buss-Durkee Hostility Inventory (BDHI), the dominance of the indicators of physical and verbal aggression, negativism and irritation was noted. In general, the index of aggressiveness in the group was 75,3; and the hostility index is 63,5. Such results indicate that the researched people often use physical force against another person; in the expression of their negative feelings they use quarrels, cries, obscene words and threats; their behavior is often the opposition, usually directed against authority and leadership, which can grow from passive resistance to active action against demands, rules and laws; they are also susceptible to irritation, and at the slightest excitement they are quick to become sharp, rude, and so on.

Such results should be objectively supported by the typical personality characteristics of the young 
men and the style of their interpersonal interaction, which we received in the processing of the FPI test (form B) and the method of diagnosis of interpersonal relations T. Liri.

Freiburg Personality Inventory (FPI) serves as an objective material for diagnosing states and personality characteristics that have foremost meaning in the process of social adaptation and behavioral regulation. We believe that the results of this test can be considered as a verification material for the previous methods. It's obvious from the mid-group distribution, the indexes of neurotic, spontaneous, and reactive aggressiveness are dominating in the group. High indicators of neurotic show the expressed signs of psychosomatic violations (this is repeatedly emphasized in the works of psychologists who carried out researches on a sample of people deprived of their liberty); spontaneous aggressiveness records an increased level of psychopathisation, which creates the preconditions for impulsive behavior; therefore, the high indicator of reactive aggressiveness, which is characterized by an aggressive attitude to the social environment and expressed desire for dominance, is also logical. Then it becomes clear that the expressed indicators of selfishness, aggressiveness and suspicion are based on the results of T. Liri's test of diagnosis of interpersonal relations.

The analysis of intercorrelation relations allowed to fix statistically significant dependencies of the correlation ratio: the "dependence-independence" tendency in the assessment of "social Self" found negative correlation relations with the indicators of openness $(r=-0,82 \mathrm{p} \leq 0,05)$ and suspicion $(\mathrm{r}=-0,86 \mathrm{p} \leq 0,05)$.

At a more thorough analysis of the obtained results, the symptom complexes of personality and behavioral characteristics were invented, which in assessing the "social Self" of the youth include extraversion, spontaneous aggressiveness and selfishness; and when evaluating "actual Self" - physical aggressiveness, irritability and negativism. The obtained data provide grounds for assertion regarding the interdependence of social maturity and the manifestation of the delinquent behavior of the young man, as evidenced by the overestimated level of aggressiveness (this is a peculiar form of desire for dominance over others, which blocks all other possible forms of realization of this need). On the other hand, self-esteem in interpersonal contacts aggravates the aggressive attitude to the social environment, which manifests itself in expressive selfishness, self-orientation and inclination to rivalry.

Thus, the study allows to state that the tendencies of "dependence-independence" in assessing "social Self" of the youth with delinquent behavior characterize them as individuals who seek to achieve a higher status in the social environment due to the expressed extraversion nature of physical, verbal and reactive aggression at the level of irritability, imbalance, personal aspirations of independence and self-centered conviction. Such psychodiagnostic indicators can serve as the main benchmarks for compiling psychocorrection programs for delinquent juveniles.

Speaking about the possible psychocorrective work on the prevention of aggressive adolescents, it should be emphasized that the psychological impact of the school psychologist and psychologists of the city administration of the Ministry of Internal Affairs of Ukraine must necessarily include elements of the consulting practice, which in the complex of psychotherapeutic measures should contain elements of sociopsychological, medical and legal influence. The resocialization efforts should also be based on the fact that authoritarian hypersocialization has a particularly negative impact on the development of the delinquent juvenile, which leads to a chaotic and often aggressive lifestyle. Therefore, we believe that in psychocorrection practice, the focus should be concentrated in the field of self-consciousness in order to find out such psychometric parameters that would contribute to overcoming the delinquent ontogenesis. They should cover not only the life plan of the young personality, but also the tactics and strategies of his individual life line both in terms of self-awareness of the delinquent past, and in the direction of optimizing the resocialization of the present and future. The course of the emotional crisis of youth self-determination can be transformed if the referral process is directed to the actualization of reflection, psychogenesis and logogenesis.

Conclusions and perspectives. Thus, in the course of the research, we defined the personality and 
behavioral content of the "social Self" of delinquent juveniles, characterized by typical personality symptoms and the style of interpersonal interaction, which are mainly localized in indicators of behavioral aggressiveness, personal independence and self-centered conviction. Among the prospects for further study, we consider it necessary to analyze the interrelation of social maturity of delinquent young men and such indicators as a strategy to overcome negative behavioral reactions, the manifestation of neurotic and somatic states, the expression of the main strategies of psychological protection and social adaptation of the youth, which significantly extends the space of psychocorrection practice with this category of persons.

\section{REFERENCES}

1. Goshovs'kij Ја.O. Ресоціалізація депривованої особистості. [Resocialization of deprived personality]. Drogobych: Kolo, 2008. - 480 p. (in Ukrainian)

2. Zmanovskaja E.V. Девиантология: Психология отклоняющегося поведения: учеб. пособие для студ. высш. учеб. заведений; [2-е изд., испр.] [Deviantology: Psychology of Deviant Behavior: Study. manual for a student. higher studying establishments; 2 ed., Ed.]. - Moscow: Akademija, 2004. - 288 p. (in Russian)

3. Maksimova N.Ju. Психологія адитивної поведінки: навч. посібник [Psychology of addictive behavior: teach. manual]. - Kyiv: Vydavnycho-poligrafichnyi centr «Kyivs'kyi universytet», 2002. - 308 p. (in Ukrainian)

4. Kon I.S. Психология ранней юности [Psychology of early youth]. - Moscow: Prosveschenie, 1989. - 256 p. (in Russian)

5. Jerikson Је. . Идентичность : юность и кризис, 2-е изд. [Identity: youth and crisis; 2nd ed.]. - Moscow: Flinta: MPSI: Progress, 2006. -352 p. (in Russian) 